\title{
sciendo
}

DOI 10.2478/sbe-2020-0041

SBE no. 15(3) 2020

\section{THE RELATIONSHIP BETWEEN ENTREPRENEURSHIP AND DIGITALIZATION - SPOTLIGHT ON THE EU COUNTRIES}

\author{
BOGOSLOV IOANA ANDREEA \\ Lucian Blaga University of Sibiu, Romania \\ LUNGU ANCA ELENA \\ Alexandru loan Cuza University of lasi, Romania
}

\begin{abstract}
:
In the current context of the modern world, economies depend on a dynamic innovative environment, the innovation actually representing one of the main facilitators of change. The economic growth has certainly led to an exponential increase with respect to the interaction between innovation and entrepreneurship. Undoubtedly, innovation depends on the entrepreneurial context and mostly on the cooperation between the market process' level actors. In order to implement the innovation in the entrepreneurial activities, there is a sine qua non condition of having the abilities to contribute as a promoter on spreading and adoption of innovation. The current innovations are, in certain situations, capitalized and they can be oriented towards gaining profit. The disparities in terms of development and the favourable evolution of the business environment are determined by multiple factors, at present the implementation of technologies representing one of them. The correlation between technology and economy exists and the effects it produces on the market reality are showcased in this article. Therefore, the purpose of the current research is to identify the correlations between the economic development and technologies adoption in the entrepreneurial field. For this purpose, quantitative methods have been used in order to strengthen the obtained results.
\end{abstract}

Key words: Entrepreneurship, Innovation, Technology, Human Development Index, DESI Index

\section{Introduction}

Under the current circumstances, the rapid digitalization is undeniable. The adoption and implementation of ICT specific instruments, tools and processes became compulsory, the results of such approaches being often recognized as competitive advantages both in terms of economic progress, and with respect to the overall society evolution.

In fact, the fierce competition existing in all fields of activity represents one of the results of globalization, a phenomenon in continuous development. In such a competitive environment, differentiation can be considered a real challenge for the business environment, innovation being impetuous. As the pace of technological change 
accelerated, was frequently related to the innovation process, being recognized for its potential to sustain the emergence of what can be called "innovative". Thus, in the present situation, the intensified competition certainly stimulates the demand in terms of indicators specific to technological innovation.

In fact, the close relationship between the two concepts, namely innovation and technology, has been considered a key factor ensuring the proper functioning and development of organizations since the early stages of the ICT field development. Referring to the attempts of business actors to respond to competitive needs in dynamic and often disruptive environments, Volonino, Robinson and Watson noted that IT application causes dramatic changes in the way organizations are designed to conduct business (Volonino, Robinson, \& Watson, 1992).

However, the acceptance of new business models guided by technological evolution foremost requires a good understanding on the correlation between the economic development and the implementation of technologies in the entrepreneurial area. Subsequently, the consequences could reside in an increased acceptability at the entrepreneurial level and the actual implementation of the change.

Therefore, the main objective of the current research is to emphasize some notable facts with respect to the existing relationship between entrepreneurial digitalization and the economic development. From a methodological perspective, a review of the specialized literature will be carried out, followed by an empirical demonstration aimed to offer a greater degree of relevance regarding the exposed results.

In fact, the empirical part implies a comprehensive analysis on the relationship between the two well-known specific indicators, namely Human Development Index and Digital Economy and Society Index, which will be analysed. The conducted research is in accordance with the existing literature and suggests the significant correlation between development and digitalization, while the selected sample and the novelty of data strengthen the analysis in question.

\section{Literature review}

In order to facilitate the understanding of a phenomenon's complexity, the development of any directions should be based on the reality and up to date studies summarizing the existing evidence in the approached research area. Identifying the potential connections between development, entrepreneurship and digitalization has been a frequently addressed subject over time.

A large part of the studies aimed to analyze the subject, highlight a strong correlation between the business activities and the achievement of high levels of human development (Wennekers, Uhlander, Thurik, 2002; Szirmai, Naudé, Goedhuys, 2011; Drucker, 2014).

The results of a relative recent study developed by the Organisation for Economic Co-operation and Development (OECD) highlighted the positive effect of digitalization in relation to the economic growth. According to the mentioned research, the small and medium enterprises (SMEs) contribute highly to the increase of the digital innovation. SMEs mission is vital in aggregating productivity growth and the result is quite evident: the 
ICT adoption is strongly connected with specialized solution support for SMEs. Moreover, in order to improve the learning processes with respect to the implementation of the digital, the organizational competences, awareness raising, capacity building and the creation of networks are extremely important (OECD, 2016).

Supporting the same idea, Bukumenko and Minina suggested that the level of development is mainly influenced by factors that characterize fixed broadband and digital public services. By taking into consideration the level of digitalization, the research identified two categories of countries: on the first hand, there are countries with a high level of digital economy and society, with a major share of services in GDP and, on the other hand, there are the developing countries, with an important share of production in GDP. Additionally, the authors noted the actual trend is characterized by spreading the modern technologies (Bakumenko, Minina, 2020).

For the selected sample of four European countries, Moroz indicated that the gap in terms of development can be "strongly visible in relation to the degree of use of ICT systems integration and the impact of ICT on the economy and society". In his study, he identified a set of factors that disadvantage the Polish economy in terms of digitalization: poor governmental influence on spreading the digitalization (e.g., electronic signature system, eID, the system records of vehicles). Other issues that affect the digitalization in Poland were identified related to individuals (e.g., gaps in software abilities) or in the area of business environment (Moroz, 2017).

The implementation of ICT contributes to the creation of new opportunities that can expand the added value. In an extensive meaning, the digitalization can be translated into the manner in which the information, machines and people are connected by the technology (Weresa, 2017).

As per Stremousova and Buchinskaia, the digitalization processes determine, to a high extent, the GDP growth and the overall economic development. Actually, the economic development itself was characterized as being the digitalization process (Stremousova, Buchinskaia, 2017). Raeskyesa and Lukas exposed the same conclusion while conducting a study regarding eight ASEAN countries (Raeskyesa, Lukas, 2019).

In a research paper, Ziemkiewicz reconfirmed the disparities between 15 European economies. Within the research, the potential of the digital economy phenomenon is also emphasized, as is expected to sustain the progress of lower developed economies and their alignment with the most developed ones. (Ziemkiewicz, 2018).

Based on the existing approaches that have been identified in the literature, we consider appropriate to analyse if and how the digital economy can influence the human development and the achievement of high progress in this regard.

\section{Methodology}

Identifying notable aspects concerning the relationship between economic development and the implementation of technologies in the entrepreneurial area involves a two-stage research process. Thus, achieving the proposed objective initially involved conducting a literature review, subsequently selecting the main indicators considered 
relevant for the purpose of the research. As the sample considered for this research consisted of European Union countries, two well-known indicators were taken into account for data collection, namely the Human Development Index - HDI and the Digital Economy and Society Index - DESI.

In order to offer a better understanding with respect to the selected indicators, a brief presentation of the indicators becomes necessary:

(1) According to the United Nations Development Programme, the aim of Human Development Index is to evaluate the development level of different countries, by taking into consideration not only the economic growth, but also the citizens and their capabilities (UNDP, 2020). In this respect, the index examines three main dimensions of the human development materialized in three key indicators with different purposes: the Life Expectancy Index referring to a long and healthy life, the Education Index focusing on being knowledgeable and the Gross National Income Index identified as having a decent standard of living.

(2) Developed by the European Commission, the Digital Economy and Society Index (DESI) analyses the digital progress the EU countries, by taking into account five relevant dimensions: Connectivity, Human capital, Use of Internet, Integration of digital technology and Digital public services (European Commission, 2020a). The main five dimensions included within the DESI Index are interconnected and considered to act as a whole.

Subsequently, the current research involved developing a statistical correlation in order to identify the relationship between the selected variables. Estimating the relationship between the dependent variable, i.e. Human Development Index, and independent variables, implied the use of statistical regression. For data collection process, official 2020 reports of European Union and United Nations have been consulted. With respect to analysing the available data, the empirical research was accompanied by the use of the statistical software SPSS.

\section{Results and Discussions}

The dominant views in the literature highlight a significant influence of digitalization on social and economic development. The activities undertaken by each of individual aim to deliver benefits and satisfy an increasing degree of needs. In the context of rapid digitalization, each individual faces new challenges. The way in which they react to changes in society is translated into disparities in terms of development. By looking at the data available for 2020, it can be easily observed that at European Union level, these discrepancies are still persistent. Table 1 depicts the values of the Human Development Index and Digital Economy and Society Index by Components in 2020.

Table 1. Human Development Index and Digital Economy and Society Index by Components, 2020 


\section{Studies in Business and Economics no. 15(3)/2020}

\begin{tabular}{|c|c|c|c|c|c|c|c|}
\hline Country & HDI & DESI & $\begin{array}{l}\text { Connec } \\
\text { tivity }\end{array}$ & $\begin{array}{l}\text { Human } \\
\text { Capital }\end{array}$ & $\begin{array}{l}\text { Use of } \\
\text { Internet }\end{array}$ & $\begin{array}{l}\text { Integration } \\
\text { of Digital } \\
\text { Technology }\end{array}$ & $\begin{array}{l}\text { Digital } \\
\text { Public } \\
\text { Services }\end{array}$ \\
\hline Finland & 0.920 & 72.30 & 59.20 & 78.40 & 76.30 & 67.00 & 87.00 \\
\hline Sweden & 0.933 & 69.73 & 64.35 & 71.70 & 75.90 & 62.20 & 79.30 \\
\hline Denmark & 0.929 & 68.88 & 64.90 & 61.20 & 75.10 & 65.10 & 87.10 \\
\hline Netherlands & 0.931 & 67.73 & 60.39 & 64.20 & 75.30 & 65.70 & 81.00 \\
\hline Malta & 0.878 & 63.73 & 58.70 & 65.90 & 65.90 & 54.90 & 78.10 \\
\hline Ireland & 0.938 & 61.80 & 45.73 & 56.40 & 62.10 & 74.30 & 80.60 \\
\hline Estonia & 0.871 & 61.05 & 51.81 & 66.60 & 65.40 & 41.20 & 89.30 \\
\hline $\begin{array}{l}\text { United } \\
\text { Kingdom }\end{array}$ & 0.922 & 60.42 & 48.85 & 63.00 & 73.30 & 54.20 & 70.80 \\
\hline Belgium & 0.916 & 58.69 & 52.04 & 50.30 & 61.10 & 65.90 & 71.70 \\
\hline Luxembourg & 0.904 & 57.92 & 63.30 & 58.20 & 58.90 & 38.25 & 73.70 \\
\hline Spain & 0.891 & 57.55 & 60.80 & 47.50 & 60.80 & 41.30 & 87.30 \\
\hline Germany & 0.936 & 56.10 & 59.40 & 56.50 & 61.60 & 39.60 & 66.40 \\
\hline Austria & 0.908 & 54.30 & 47.22 & 56.70 & 54.00 & 40.50 & 80.80 \\
\hline Lithuania & 0.858 & 53.88 & 48.89 & 43.80 & 57.30 & 49.50 & 81.40 \\
\hline France & 0.901 & 52.20 & 49.80 & 47.50 & 53.00 & 42.10 & 76.70 \\
\hline Slovenia & 0.896 & 51.21 & 50.22 & 48.30 & 51.70 & 41.00 & 70.80 \\
\hline $\begin{array}{l}\text { Czech } \\
\text { Republic }\end{array}$ & 0.888 & 50.81 & 44.94 & 48.70 & 54.10 & 49.60 & 62.40 \\
\hline Latvia & 0.847 & 50.71 & 61.65 & 35.10 & 54.00 & 28.30 & 85.10 \\
\hline Portugal & 0.847 & 49.57 & 53.85 & 37.80 & 48.10 & 40.90 & 75.10 \\
\hline Hungary & 0.838 & 47.56 & 59.82 & 41.90 & 56.00 & 25.30 & 57.80 \\
\hline Croatia & 0.831 & 47.54 & 41.11 & 49.20 & 55.40 & 41.40 & 55.80 \\
\hline Slovakia & 0.855 & 45.18 & 47.50 & 41.80 & 53.40 & 32.50 & 55.60 \\
\hline Poland & 0.865 & 44.95 & 51.33 & 37.30 & 49.60 & 26.20 & 67.40 \\
\hline Cyprus & 0.869 & 43.99 & 38.45 & 35.80 & 54.51 & 34.50 & 69.00 \\
\hline Italy & 0.880 & 43.66 & 49.99 & 32.40 & 44.54 & 31.30 & 67.50 \\
\hline Romania & 0.811 & 39.96 & 56.20 & 33.10 & 35.97 & 24.88 & 48.40 \\
\hline Greece & 0.870 & 37.34 & 33.41 & 34.80 & 46.15 & 28.21 & 51.50 \\
\hline Bulgaria & 0.813 & 36.43 & 38.52 & 33.90 & 36.61 & 17.84 & 61.80 \\
\hline $\begin{array}{l}\text { European } \\
\text { Union }\end{array}$ & 0.883 & 52.60 & 50.04 & 49.30 & 58.00 & 41.30 & 72.00 \\
\hline
\end{tabular}

Source: Based on data provided by the Human Development Index and Digital Economy and Society Index by Components, 2020

Table 2 illustrates the existing correlations between the considered variables, i.e. the Human Development Index and each of five components included in the Digital Economy and Society Index, based on the obtained results after data processing using the SPSS statistical software. The statistically significant correlations for the Human Development Index and each of the five components of Digital Economy and Society Index are easily observed as Sig coefficient is less than 0.05 .

Very strong correlations are highlighted between Human Development Index and Integration of Digital Technology (correlation coefficient $=0.769$ ), Human Development Index and Use of Internet (correlation coefficient = 0.747), Human Development Index and Human Capital (correlation coefficient $=0.711$ ), while the correlation between Human Development Index and Digital Public Services (correlation coefficient $=0.536$ ) is weaker, but still a strong one. However, based on our results, the Human Development Index and Connectivity dimension are poorly correlated from a statistical point of view, the correlation coefficient being only 0.346 . 
Table 2. Correlations Between the Independent Variables (the components of DESI Index) and the Dependent Variable (Human Development Index)

\begin{tabular}{|c|c|c|c|c|c|c|c|}
\hline \multicolumn{8}{|l|}{ Correlations } \\
\hline & & HDI & Connectivity & $\begin{array}{l}\text { Human } \\
\text { Capital }\end{array}$ & \begin{tabular}{|l} 
Use \\
Internet
\end{tabular} & $\begin{array}{l}\text { Integration o } \\
\text { Digital } \\
\text { Technology }\end{array}$ & $\begin{array}{l}\text { Digital } \\
\text { Public } \\
\text { Services }\end{array}$ \\
\hline \multirow{6}{*}{$\begin{array}{l}\text { Pearson } \\
\text { Correlation }\end{array}$} & HDI & 1.000 & .346 & .711 & .747 & .769 & .536 \\
\hline & Connectivity & .346 & 1.000 & .464 & .523 & .308 & .495 \\
\hline & Human Capital & .711 & .464 & 1.000 & .884 & .762 & .579 \\
\hline & Use of Internet & .747 & .523 & .884 & 1.000 & .805 & .636 \\
\hline & \begin{tabular}{|l|} 
Integration \\
Digital \\
Technology \\
\end{tabular} & .769 & .308 & .762 & .805 & 1.000 & .569 \\
\hline & \begin{tabular}{|ll} 
Digital & Public \\
Services & \\
\end{tabular} & .536 & .495 & .579 & .636 & .569 & 1.000 \\
\hline \multirow{6}{*}{$\begin{array}{l}\text { Sig. } \\
\text { (1-tailed) }\end{array}$} & HDI & . & .033 & .000 & .000 & .000 & .001 \\
\hline & Connectivity & .033 & . & .006 & .002 & .052 & .003 \\
\hline & Human Capital & .000 & .006 & & .000 & .000 & .000 \\
\hline & Use of Internet & .000 & .002 & .000 & & .000 & .000 \\
\hline & \begin{tabular}{|l|} 
Integration of \\
Digital \\
Technology \\
\end{tabular} & .000 & .052 & .000 & .000 & . & .001 \\
\hline & $\begin{array}{ll}\text { Digital Public } \\
\text { Services }\end{array}$ & .001 & .003 & .000 & .000 & .001 & . \\
\hline
\end{tabular}

Source: Authors' results after data processing using SPSS software

The Integration of Digital Technology is one of the most important aspects in increasing development and, consequently, achieving a high degree of Human Development Index. Moreover, it is added to Use of Internet and Human Capital. Similar results can be founded in the specialty literature. A significant connection between the digitalization level and the development of a country, as well as the innovative and entrepreneurial activities was discovered by Jovanović et al. in a recent study (Jovanović, M., Dlačić, J., Okanović, M., 2018).

Comprising the correlation coefficient $(R)$ and the determination coefficient $(R$ Square), Table 3 illustrates the model summary. Regarding the correlation coefficient (R), it indicates the existence or non-existence of a correlation between variables, fluctuating between -1 and +1 . The estimated value of the determination ratio $R$ Square is 0.590 , which means that the variation of the Human Development Index is $59 \%$ explained by the variation of the Digital Economy and Society Index. Moreover, the estimated correlation report is 0.768 , which shows that there is a strong relationship between the Human Development Index and the overall Digital Economy and Society Index.

\section{Table 3. Model Summary}

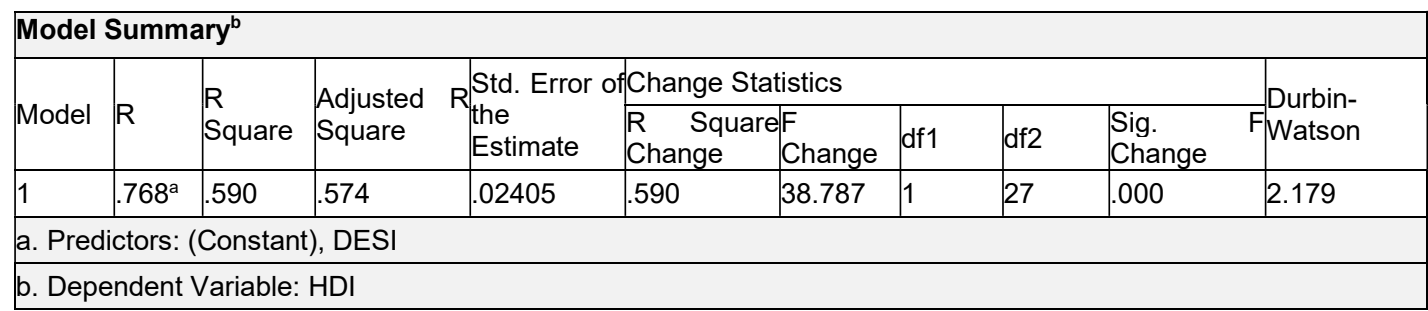

Source: Authors' results after data processing using SPSS software 
Analysing the Table 4, namely ANOVA statistical test, there can be noted the Sig $=0.000$ (generally, this can take values under 0.05 ) which states the model is statistically correct. Therefore, the level of digitalization of economy and society influences the level of human development.

Table 4. ANOVA statistical test - dependent variable Human Development Index

\begin{tabular}{|l|l|l|l|l|l|l|}
\hline \multicolumn{7}{|l|}{ ANOVA $^{\text {a }}$} \\
\hline Model & Sum of Squares & Df & Mean Square & F & Sig. \\
\hline \multirow{4}{*}{1} & Regression & .022 & 1 & .022 & 38.787 & $.000^{\mathrm{b}}$ \\
\cline { 2 - 7 } & Residual & .016 & 27 & .001 & & \\
\cline { 2 - 7 } & Total & .038 & 28 & & & \\
\hline \multicolumn{2}{|l|}{ a. Dependent Variable: HDI } \\
\hline
\end{tabular}

Source: Authors' results after data processing using SPSS software

Table 5. Coefficients

\begin{tabular}{|c|c|c|c|c|c|c|c|c|c|c|}
\hline \multicolumn{11}{|l|}{ Coefficients $^{a}$} \\
\hline \multirow{2}{*}{ Model } & \multicolumn{2}{|c|}{$\begin{array}{l}\text { Unstandardized } \\
\text { Coefficients }\end{array}$} & \multirow{2}{*}{$\begin{array}{l}\begin{array}{l}\text { Standardized } \\
\text { Coefficients }\end{array} \\
\text { Beta }\end{array}$} & \multirow{2}{*}{$\mathrm{T}$} & \multirow{2}{*}{ Sig. } & \multicolumn{2}{|c|}{$\begin{array}{l}95.0 \% \text { Confidenc } \\
\text { Interval for B }\end{array}$} & \multicolumn{3}{|c|}{ Correlations } \\
\hline & $B$ & $\begin{array}{l}\text { Std. } \\
\text { Error }\end{array}$ & & & & $\begin{array}{l}\text { Lower } \\
\text { Bound }\end{array}$ & $\begin{array}{l}\text { Upper } \\
\text { Bound }\end{array}$ & $\begin{array}{l}\text { Zero- } \\
\text { order }\end{array}$ & Partial & Part \\
\hline \multirow{2}{*}{\begin{tabular}{|l|l|}
1 & (Constant) \\
\cline { 2 - 2 } & DESI \\
\end{tabular}} & .725 & .026 & & 28.07 & .000 & .672 & .778 & & & \\
\hline & .003 & .000 & .768 & 6.22 & .000 & .002 & .004 & .768 & .768 & .768 \\
\hline
\end{tabular}

Source: Authors' results after data processing using SPSS software

In column B, the value of the coefficients can be observed, while the Std. Error column shows the standard error of coefficient through the standard deviation in the random distribution of the coefficient. Beta Column points out the changes in Human Development Index if the independent variable (DESI Index) is modified by one standard deviation. The Sig Test demonstrates that the model is statistically correct $($ Sig $<0.05)$, which means that the Human Development Index is influenced by the Digital Economy and Society Index.

The equation for the linear regression is the following: $Y_{x}=0.725+0.003 x$. Therefore, the statistical processing of the available data shows that the Human Development Index is significantly influenced by the fluctuations in the overall digitalisation of the economy and society. In point of fact, about $59 \%$ of the fluctuations recorded at HDI level have digitalization as the main determinant.

Considering the existent views in the literature and the results of the present research, several issues can be highlighted:

(1) In the European Union area, Human Development Index has registered the highest values in Finland, Sweden, Denmark and Netherlands. In the mentioned countries, we also identified the highest values of the Digital Economy and Society Index. At the opposite side, Italy, Romania, Greece and Bulgaria ranked the lowest.

(2) The digitization of public services has emerged as a consequence of the needs of new Internet users. In this respect, most of them would like to be able to communicate easily with government institutions by using online services. There is a need of easy 
communication with the public administration. In order to count this, the e-Government Indicator is used, measuring the percent of the Internet users that submit the forms through online channels. Introducing the electronic documents in order to facilitate the communication with the citizens represents an important achievement for Finnish, Danish and Estonian governments: the Internet users can submit the files to public authorities. In the same field of implementing the e-Documents strategy, Malta, Germany and Spain have made important improvements in the last years (European Commission, 2020b). Another issue of the e-Government is related to pre-filled forms, which can facilitate (or not) the relationship between individuals, companies and institutions. On top of this ranking, we can find Malta, Estonia, Lithuania and Latvia. The lowest values of implementing the pre-filled forms, with scoring below 30/100, are Romania, the UK and Greece. The digitalization of business environment asks for digital public services (in this field). In order to measure the level to which public services are interoperable and work outside the national borders, the Digital Public Services for Businesses indicator can be used. In 2020, 18 European countries recorded scores higher than 90 points of 100 . The results obtained for countries such Romania, Greece and Croatia were below 70 points of 100.

(3) The integration of digital technologies represents a fundamental step in developing the business environment. By taking into consideration the importance of Internet adoption in entrepreneurial activities, we can state that this attitude can determine a competitive advantage in the market. In the European Commission report about integration of digital technology, the importance of digitalization is highlighted as follows: digital transformations help the entrepreneurs to identify new opportunities and, more than this, contribute to developing the existing activities by new and trustworthy technologies. In order to measure the level of digitalization with respect to entrepreneurial activities and ecommerce activities, the Integration of Digital Technology indicator can be used (European Commission, 2020c). By analysing the available data, the discrepancies between countries can be observed once again: Ireland, Finland, Belgium, the Netherlands, Denmark and Sweden are the European leaders in terms of integration of new technologies. At the opposite side, countries like Bulgaria, Romania, Hungary, Poland, Greece and Latvia can be found, where the integration the digital technologies is still a susceptible issue.

E-Commerce development and implementation represents one of the most important results of digital technologies integration. At this point, Ireland, Czech Republic, Denmark, Belgium and Sweden are on top of selling online. Less favourable results regarding e-Commerce adoption are encountered by countries like Bulgaria, Greece, Luxembourg and Romania. According to European Commission Report, approximately $78 \%$ of large enterprises adopted new technologies (e.g. Enterprise Resource Planning) comparing to only $33 \%$ of SMEs.

(4) The COVID-19 pandemic demonstrated, once again, the importance of digital competences and skills of the individuals. Only $58 \%$ of European citizens hold basic digital skills. In 2019, $85 \%$ of Europeans used Internet, but the major problem is related to the discrepancies between countries. For example, on top of the ranking, we can find Netherlands (80\%), Finland $(77 \%)$ and the UK $(75 \%)$ where individuals possess at least basic software skills. In addition, by analysing the Human Capital dimension subcomponents, i.e. Internet User Skills and Advanced Skills and Development, the disparities 
between states can be easily noticed: only $35 \%$ of Romanians and $31 \%$ of Bulgarians possess basic software skills. This situation can be explained by a comprehensive cluster of factors, such as the level of education, economic, political and financial reasons, culture, and others.

\section{Conclusions}

Given the complexity of the modern economy and society, identifying potential factors influencing the development could be considered an indisputable challenge. As the evolution of the ICT field is a continuous and extremely fast one, its impact on the economic development has been recognized, directly proportional beneficial effects often being reported. Therefore, a good understanding of the effects of digitalisation on economic and human development as a whole becomes necessary and can lay the foundations for action that will lead to favourable progresses.

The phenomenon under analysis in the present research represents a highly debated theme in the current context of digitalization and globalisation, as correlating the entrepreneurial activity to the technological adoption is supposed to serve as a competitive advantage. Most of the studies developed over time indicate the existence of a close interdependence between the two mentioned spheres. However, increasing the relevance regarding the existing visions can only be sustained by direct observation of the reality and the empirical analysis on the current situation.

After analysing the available data, it can be noted that the overall Human Development Index is highly influenced by the fluctuations in the digitalisation of the economy and society in general. The digitalization represents the main determinant for about $59 \%$ of the fluctuations recorded at HDI level. Additionally, the process of digitalizing has led to disparities in the development of the European Union's Member States, materialized by the existence of extremes regarding the scores obtained.

In the entrepreneurial activity sphere, the process of digitalization has always been a difficult task and the effects on development are visible. There are significant disparities in terms of digitalization and implementation of technologies in the entrepreneurial area, while the overall development of society and the economy is closely linked to digitalization. However, there are European Union countries that have managed to adopt and implement digitization through various channels.

Regarding the limitations of the research, we assume that the sample considered, i.e. the EU Member States, can be considered limited for certain interests. However, we consider that the research can serve as a good starting point when it comes to analysing the interdependencies between entrepreneurial activity and digitalization. Future directions of research are directed towards the inclusion of a larger number of states in the analysis and the consideration of several relevant indicators.

\section{References}

Bakumenko, L., Minina, E.A. (2020). International Index of Digital Economy and Society (I-DESI): Trends in the Development of Digital Technologies. Statistics and Economics 17(2), 40-54. DOI: https://doi.org/10.21686/2500-3925-2020-2-40-54 
Drucker, P. (2014). Innovation and entrepreneurship. Routledge.

European Commission. (2019, September 13). Digital Economy and Society Index by Components.

Retrieved from Digital Agenda: https://digital-agenda-data.eu/charts/desicomponents\#chart=\{\%22indicator\%22:\%22desi_1_conn\%22,\%22breakdown-

group\%22:\%22desi_1_conn\%22,\%22unit-measure\%22:\%22egov_score\%22,\%22timeperiod $\% 22: \% 222020 \% 22\}$

European Commission. (2020a). Digital Economy and Society Index (DESI) 2020 Questions and Answers. Retrieved from Ec.Europa.eu:

https://ec.europa.eu/commission/presscorner/detail/en/QANDA_20_1022

European Commission. (2020b). Digital Economy and Society Index (DESI) 2020 - Digital Public Services. Bruxelles: EuropeanCommission.

European Commission. (2020c). Digital Economy and Society Index (DESI) 2020 - Integration of digital technology. Bruxelles: European Commission.

Haltiwanger, J., Jarmin, R.S. (2000). Measuring the digital economy. In E. K. Brynjolfsson, Understanding the Digital Economy: Data, Tools, and Research, (pp. 13-33). Cambridge: The MIT Press.

Jovanović, M., Dlačić, J., Okanović, M. (2018). Digitalization and Society's Sustainable Development - Measures and Implications. Zbornik radova Ekonomskog fakulteta u Rijeci : časopis za ekonomsku teoriju i praksu, Vol. 36 No. 2, 905-928. DOI: https://doi.org/10.18045/zbefri.2018.2.905

Levi Jaksić, M., Jovanović, M., Petković, J. (2015). Technology Entrepreneurship in the Changing Business Environment - A Triple Helix Performance Model. Amfiteatru Economic, Vol. 17, No. 38, 422-440.

Moroz, M. (2017). The Level of Development of the Digital Economy in Poland and Selected European Countries: a Comparative Analysis. Foundations of Management, Vol. 9, 175-190. DOI: https://doi.org/10.1515/fman-2017-0014

OECD. (2016). Stimulation Digital Innovation for Growtsh and Inclusiveness, OECD Digital Economy Papers No. 256. Paris: OECD Publishing.

Ordieres-Meré, J., Remón, T.P., Rubio, J. (2020). Digitalization: An Opportunity for Contributing to Sustainability From Knowledge Creation. Sustainability, 12, 1460, 1-21. DOI: https://doi.org/10.3390/su12041460

Oswald, G. K. (2017). Shaping the Digital Enterprise: Trends and Use Cases in Digital Innovation and Transformation. Switzerland: Springer International Publishing.

Raeskyesa, D.G.S., Lukas, E.N. (2019). Does Digitalization Increase Economic Growth? Evidence from ASEAN 8 Countries. Jurnal Ekonomi Indonesia, 8(2), 267-278.

Stavytskyy, A., Kharlamova, G., Stoica, E.A. (2019). The Analysis of the Digital Economy and Society Index in the EU. Baltic Journal of European Studies, Vol. 9, No. 3(28) , 245-261. DOI: https://doi.org/10.1515/bjes-2019-0032

Stremousova, E., Buchinskaia, O. (2017). Some Approaches to Evaluation Macroeconomic Efficiency of Digitization. Business, Management and Educatio, 17(2), 232-247. DOI: https://doi.org/10.3846/bme.2019.11326

Szirmai, A., Naudé, W., \& Goedhuys, M. (2011). Entrepreneurship, innovation, and economic development. Oxford University Press. DOI:10.1093/acprof:oso/9780199596515.001.0001

UNDP. (2020, September 10). United Nations Development Programme. Retrieved from Human Development Index (HDI): http://hdr.undp.org/en/content/human-development-index-hdi

Volonino, L., Robinson, S., \& Watson, H. (1992). EIS And Organizational Change. Proceedings of the IFIP Tc8/wg 8.3 Working Conference on Decision Support Systems: Experiences and Expectations (pp. 309-321). Fontainebleau: Elsevier B.V. DOI: https://doi.org/10.1016/B978$\underline{0-444-89673-5.50028-8}$ 
Wennekers, S., Uhlander, L. M., \& Thurik, R. (2002). Entrepreneurship and its Conditions: A Macro Perspective. International Journal of Entrepreneurship Education, 1(1), 25-64.

Weresa, M. (2017). Innovation, Human Capital and Competitiveness in Central and Eastern Europe with Regard to the Challenges of a Digital Economy. In B. D. Galgóczi, Condemned to Be Left Behind? Can Central and Eastern Europe Emerge from its Low-Wage Model? (pp. 81-109). Brussels: ETUI .

Ziemkiewicz, M. (2018). Digital economy in the old European Union Member. https://msed.vse.cz/msed_2018/article/129-Pietrzak-Michal-paper.pdf, 1431-1439. 